\title{
Association Between HLA genotypes and Oxcarbazepine-induced Cutaneous Adverse Drug Reactions: A Systematic Review and Meta- Analysis
}

\author{
Wimonchat Tangamornsuksan ${ }^{1,3}$, C.N. Scholfield ${ }^{1,3}$, Manupat Lohitnavy ${ }^{1,2,3^{*}}$ \\ 1. Center of Excellence for Environmental Health \& Toxicology, Faculty of Pharmaceutical Sciences, Naresuan \\ University, Phitsanulok, Thailand. 2. Pharmacokinetic Research Unit, Faculty of Pharmaceutical Sciences, Naresuan \\ University, Phitsanulok, Thailand. ${ }^{3}$. Department of Pharmacy Practice, Faculty of Pharmaceutical Sciences, Naresuan \\ University, Phitsanulok, Thailand.
}

Received November 21, 2017; Revised, January 22, 2018; Accepted, January 23, 2018; Published, January 25, 2018.

\#

ABSTRACT - PURPOSE: To systematically review and quantitatively synthesize associations between $H L A$ genotypes and oxcarbazepine-induced cutaneous adverse drug reactions (OXC-cADRs), including StevensJohnson syndrome (SJS) and maculopapular rash. METHODS: Studies investigating associations between HLA genotypes and OXC-cADRs were systematically searched irrespective of language, in PubMed, HuGENet (Human Genome Epidemiology Network), and the Cochrane Library from their inception until January, 2017. Inclusion criteria were studies investigating associations between HLA genotypes and OXCcADRs that reported sufficient data for calculating the frequency of HLA genotype carriers among cases and controls. Overall odds ratios (ORs) with corresponding 95\%CIs were calculated using a random-effects model to determine the association between HLA genotypes and OXC-cADRs. RESULTS: The initial searches identified 91 articles, of which 6 studies met the selection criteria. The studies included 229 patients with OXC-cADRs, 251 OXC-tolerant patients, and 2,358 participants from general populations of Han Chinese, Korean, and Thai ethnicities. Associations between $H L A-B * 1502$ and OXC-induced SJS were found in both the general population $[\mathrm{OR}=30.2(95 \% \mathrm{CI}=3.45-264)]$ and in OXC-tolerant individuals $[\mathrm{OR}=26.4$ $(95 \% \mathrm{CI}=7.98-87.6)]$. An association between the $H L A-B * 1502$ and $\mathrm{OXC}$-induced maculopapular rash was found in the general population $[\mathrm{OR}=5.67(95 \% \mathrm{CI}=2.03-15.9)]$ while $H L A-A * 3101$ also associated with $\mathrm{OXC}$ induced maculopapular rash $[$ overall $\mathrm{OR}=29.2(95 \% \mathrm{CI}=6.70-128)]$. CONCLUSIONS: Strong associations between the HLA-B*1502 and OXC-cADRs (SJS and maculopapular rash) were found in both controls from general population and $\mathrm{OXC}$-tolerant groups. There was also an association between $H L A-B * 3101$ and $\mathrm{OXC}$ induced maculopapular rash. For patient safety, genetic screening especially for $H L A-B * 1502$ prior to $\mathrm{OXC}$ therapy at least in these closely related ethnicities is warranted. Further studies need to better define other ethnicities at risk and a wider range of MHC gene subtypes.

This article is open to POST-PUBLICATION REVIEW. Registered readers (see "For Readers") may comment by clicking on ABSTRACT on the issue's contents page.

\section{INTRODUCTION}

Oxcarbazepine (OXC) is a keto-analogue of carbamazepine (CBZ) and approved as a monotherapy or adjunctive therapy to treat partial seizures in adults and children (1). It has less severe cutaneous adverse drug reactions (cADRs) and thus a safer choice for CBZ-intolerant patients (2). $\mathrm{OXC}$-cADRs vary from mild maculopapular rash to severe reactions (i.e., Stevens-Johnson syndrome/toxic epidermal necrolysis, SJS/TEN), and drug rashes with eosinophilia and systemic symptoms with eosinophilia and systemic symptoms, DRESS). However, the most common OXC-cADR is maculopapular rash (3). 25-78\% of CBZ-hypersensitive patients develop a cross reaction with $\mathrm{OXC}$, while $29-40 \%$ of OXC- induced hypersensitive patients cross react with CBZ (4-6).

Several studies suggested that most cADRs caused by epileptic drugs (e.g., CBZ, phenytoin, lamotrigine) are drug-specific immune responses through human leukocyte antigens (HLAs) $(7,8)$. HLA is a gene group encoding the major histocompatibility complex (MHC) located on chromosome 6 in humans $(9,10)$. MHCs are cellsurface receptors that capture and present self- and pathogen-derived peptides to T-cell receptors. The associations among MHC class I and II and OXC-

Corresponding Author: Manupat Lohitnavy, Center of Excellence for Environmental Health \& Toxicology, Faculty of Pharmaceutical Sciences, Naresuan University, Phitsanulok, Thailand, Email: manupat1@nu.ac.th 


ABBREVIATIONS: BFDE = bullous fixed
drug eruption; cADRs = cutaneous adverse drug
reactions; CBZ = carbamazepine; CI =
confidence intervals; DRESS = drug rash with
eosinophilia and systemic symptoms; HLAs =
human leukocyte antigens; HuGENet = Human
Genome Epidemiology Network; HWE =
Hardy-Weinberg equilibrium; MHC = major
histocompatibility complex; NOS = The
Newcastle-Ottawa scale; OR = odds ratio; OXC
$=\quad$ oxcarbazepine; OXC-cADRs =
oxcarbazepine-induced cutaneous adverse drug
reactions; PCR= polymerase chain reaction; SJS
$=$ Stevens-Johnson syndrome; TEN = Toxic
epidermal necrolysis

cADRs have been studied in several epidemiological studies (11-14). However, these previous studies have shown a wide range of $H L A$ genotypes (i.e., $H L A-A * 3101, H L A-B^{*} 1502$ ), OXC-cADRs (i.e., maculopapular rash, SJS/TEN), and the magnitude of associations. A major limitation of the individual studies is the low incidence of OXC-cADRs. Small sample sizes among those studies may contribute observed variations. An important part of reducing cADRs is an understanding of population risks as well as HLA genotyping before drug treatment. Therefore, to better assess these risks, we aimed to review all relevant studies and to quantitatively synthesize the magnitude of the associations using a systematic review and meta-analysis technique.

\section{METHODS}

\section{SEARCH STRATEGY AND SELECTION CRITERIA}

PubMed, Human Genome Epidemiology Network (HuGENet) and the Cochrane Library were systematically searched from their inception until January 2017 using keyword combinations or synonyms for "HLA genotypes" and "oxcarbazepine" without language or study design restrictions. Only human studies were included. Additional studies were retrieved from bibliographies of the included articles. Two reviewers (WT, ML) independently screened titles and/or abstracts for relevance followed by full-text article assessments for inclusion. Studies were included if: (1) HLA genotypes/OXC-cADRs associations were investigated; (2) all patients received OXC before HLA genotypes screening, and; (3) sufficient data for calculating the frequency of HLA genotypes carriers were reported. When studies shared the same population, the one reporting most data and patients was selected. Where data was insufficient for meta-analysis, additional data was sought from corresponding authors.

Two reviewers (WT, ML) extracted data by study design, eligibility criteria, definition, and diagnostic criteria for cases and controls, patient demographics, dose and duration of OXC exposure, the HLA genotyping technique and Hardy-Weinberg equilibrium (HWE) information. The genotype frequencies were examined by the HWE to determine whether the patients from the selected studies were representative of the population $(15,16)$. Study quality used the Newcastle-Ottawa scale (NOS) comprising three domains: selection, comparability, and outcome or exposure (17). All disagreements throughout were resolved by discussion between the reviewers until consensus was made.

\section{DATA ANALYSIS}

The included studies demonstrating an association between HLA genotypes and OXC-cADRs were characterized and summarized based on the most recent data. The overall odds ratios (ORs) with $95 \%$ confidence intervals (CIs) were calculated to determine associations between HLA genotypes and OXC-cADRs. All analyses were performed using the DerSimonian and Laird method under a random-effects model (18). The analyses were also performed separately on studies using different types of control (e.g., general population or OXCtolerant control), different design, different $H L A$ genotypes, and different type of OXC-cADRs.

Information regarding HLA genotypes was obtained from the Allele Frequency Net Database, a genetic database, and from studies reporting allele frequencies of the genes; this group was defined as a general population control. Whereas OXC-tolerant control was defined by information of HLA genotypes in the control group obtained from patients who received OXC without any history of cADRs.

Statistical heterogeneity was assessed via the Q-statistics and I-squared tests. P-values $\leq 0.10$ indicated heterogeneity between studies (19). Isquared values of $25 \%, 50 \%, 75 \%$ denote a low, moderate, and high degree of heterogeneity across studies (20). All statistical analyses were performed using the R program (version 3.4.0) ( $\mathrm{R}$ foundation for statistical computing, 2017). 


\section{RESULTS}

\section{SEARCH STRATEGY AND SELECTION CRITERIA}

Searching results are depicted in Figure 1. In brief, 91 articles were identified, which was whittled down to 6 studies that met our criteria $(12-14,21-$ 23). These comprised 229 patients with OXCcADRs, 251 OXC-tolerant patients, and 2,358 participants from general populations $(12-14,21$ $23)$. Five studies were case-controlled $(12,14,21$ 23) which formed our systematic review and metaanalysis, and one was a prospective cohort (13) (Table 1).

\section{STUDY CHARACTERISTICS AND QUALITY ASSESSMENT}

Characteristics of the included studies are summarized in Table 1 and 2. Mean ages of included patients were 26.7 years in cases (12-14, 21-23) and 34.0 years (22) in controls; males made up $44.3 \%$ (58 of 131) of cases (12-14, 21-23) and $8.9 \%$ (11 of 123) of controls (22). Age and gender data were not reported where controls were from the general population. The mean dose of OXC was $315.4 \mathrm{mg} /$ day (range 75-600 mg/day) (12-14, 22). The mean delay in appearance of OXCcADRs after initiating treatment was 13.9 days (rang 1-53 days) $(12-14,22)$. The included studies identified HLA genotypes using polymerase chain reaction (PCR) as a sequence-based typing technique $(12,23), \quad P C R$ sequence specific oligonucleotide primers (21) and PCR sequence specific primers $(13,14,22)$. No study reported sample-size calculations before recruiting patients, nor HWE information. A mean quality assessment using NOS for case control studies $(12,14,21-23)$ was 5.8 (range 5-6), whereas NOS scale of the cohort study (13) was 9 (Table 2).

\section{SYSTEMATIC REVIEW AND META- ANALYSIS RESULTS MHC class I and OXC-cADRs \\ HLA-A genotypes}

The associations between HLA-A genotypes and OXC-cADRs of the included studies are summarized in Table 3. Two studies $(21,24)$ investigated associations between $H L A-A$ genotypes (i.e., $H L A-A^{*} 3101$ and $H L A-A * 3201$ ) and several types of OXC-cADRs (i.e., maculopapular rash, SJS, DRESS and BFDE). However, there was only sufficient data to assess the association between $H L A-A * 3101$ and OXCinduced maculopapular rash that could be metaanalysed. Associations between $H L A-A * 3201$ and OXC-induced maculopapular rash were determined by Moon et al (21) in general population control and OXC-tolerant groups. An association between $H L A-A * 3201$ and OXCinduced maculopapular rash was found in general population controls (overall $\mathrm{OR}=8.46$, $95 \% \mathrm{CI}=1.37-52.2$ ) (Table 3). Moon et al (21) and Chen et al (23) found 8 out of $53 H L A-A * 3101$ carriers in their cases general population controls, the numbers of and controls were 5 out of 579 . We found an association between $H L A-A^{*} 3101$ and OXC-induced maculopapular rash in the general population controls (overall $\mathrm{OR}=29.2$, $95 \% \mathrm{CI}=6.70-128 ; I^{2}=0.0 \%, p=0.45$ ) (Figure 2). In OXC-tolerant controls, the number of HLA$A^{*} 3101$ carriers in cases was 6 out of 35 and 15 out of 156 for controls. However, there was no statistically significant association between $H L A$ $A * 3101$ and $\mathrm{OXC}$-induced maculopapular rash in OXC-tolerant group (Figure 2).

\section{HLA-B genotypes}

The associations between HLA-B genotypes and OXC-cADRs of the included studies are summarized in Table 3. Among all of the included studies (12-14, 21-23), 42 different $H L A-B$ genotypes and several types of OXC-cADRs are investigated. Associations between $H L A-B^{*} 1501$, $H L A-B^{*} 1502$, and $H L A-B^{*} 1511$ and OXC-cADRs could be included into our further meta-analyses. Associations between $H L A-B * 1502$ and OXCcADRs were identified.

All included studies (12-14, 21-23) investigated associations between $H L A-B * 1502$ and different types of OXC- types of OXC-cADRs. Two studies $(14,23)$ investigated associations between $H L A-B * 1502$ and OXC-induced SJS in general population controls and OXC-tolerant group. In the general population groups, there were $4 H L A-B^{*} 1502$ carriers out of 5 cases and 14 out of 137 for controls. The overall OR was 30.2 (95\% CI $=3.45-264 ; I^{2}=0.0 \%, p=0.80$ ) (Figure $3 \mathrm{~A}$ and Table 3 ). In OXC-tolerant controls, there were $13 H L A-B^{*} 1502$ carriers out of 19 cases and 8 out of 109 for controls. The overall OR was 26.4 (95\% $\mathrm{CI}=7.98-87.6 ; I^{2}=0.0 \%, p=0.64$ ) (Figure $3 \mathrm{~A}$ and Table 3).

All included studies (12-14, 21-23) investigated associations between $H L A-B^{*} 1502$ and $\mathrm{OXC}$-induced maculopapular rash. However, only case control studies were meta-analysed. In the case control studies (12, 14, 21-23), the incidence of $H L A-B^{*} 1502$ carriers in cases, general population control, and $\mathrm{OXC}$-tolerant groups were 6 out of 67,51 out of 1,930 , and 15 out of 216 respectively. In general population controls, the 
overall OR was $5.67\left(95 \% \mathrm{CI}=2.03-15.9 ; I^{2}=0.0 \%\right.$, $p=0.76$ ) (Figure 3B and Table 3).

In addition, we combined numbers of OXCinduced maculopapular rash and OXC-induced SJS events in to further investigate their associations between $H L A-B^{*} 1502$ and OXCinduced maculopapular rash and SJS. In general population controls only, $H L A-B^{*} 1502$ was associated with OXC-induced maculopapular rash and SJS; overall OR was $7.15(95 \% \mathrm{CI}=2.64-19.4$; $I^{2}=0.0 \%, p=0.50$ ) (Figure $3 \mathrm{C}$ and Table 3 ).

Only Moon et al (21) studied the $H L A-B * 4002$ genotype and $\mathrm{OXC}$-induced maculopapular rash by comparing cases with either the general population $[\mathrm{OR}=4.04(95 \% \mathrm{CI}=1.83-8.90)]$ or with their OXC-tolerant group $[\mathrm{OR}=4.33$ $(95 \% \mathrm{CI}=1.36-13.8)]$ (Table 3$)$.

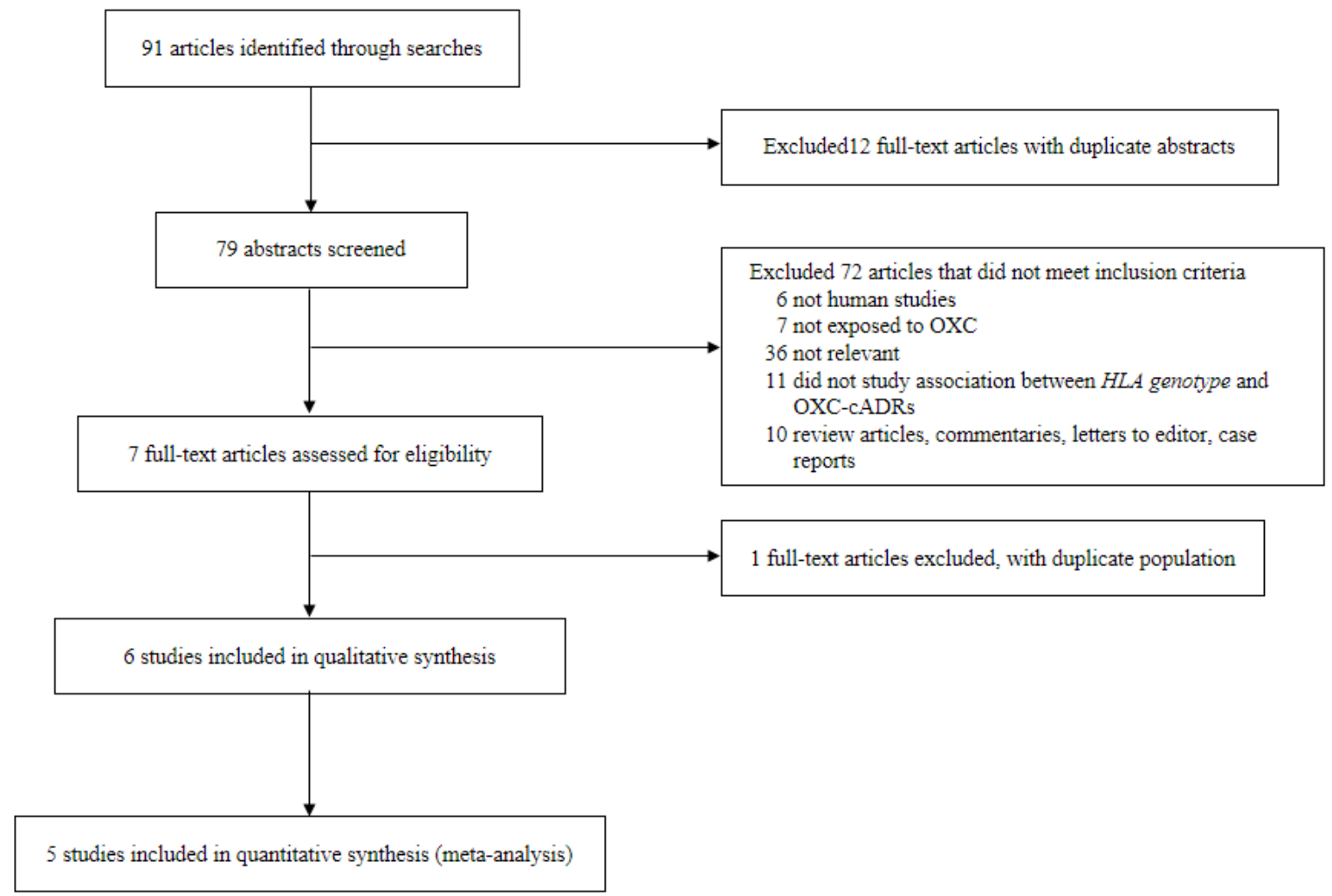

Figure 1 Summary of study identification, inclusion, and exclusion

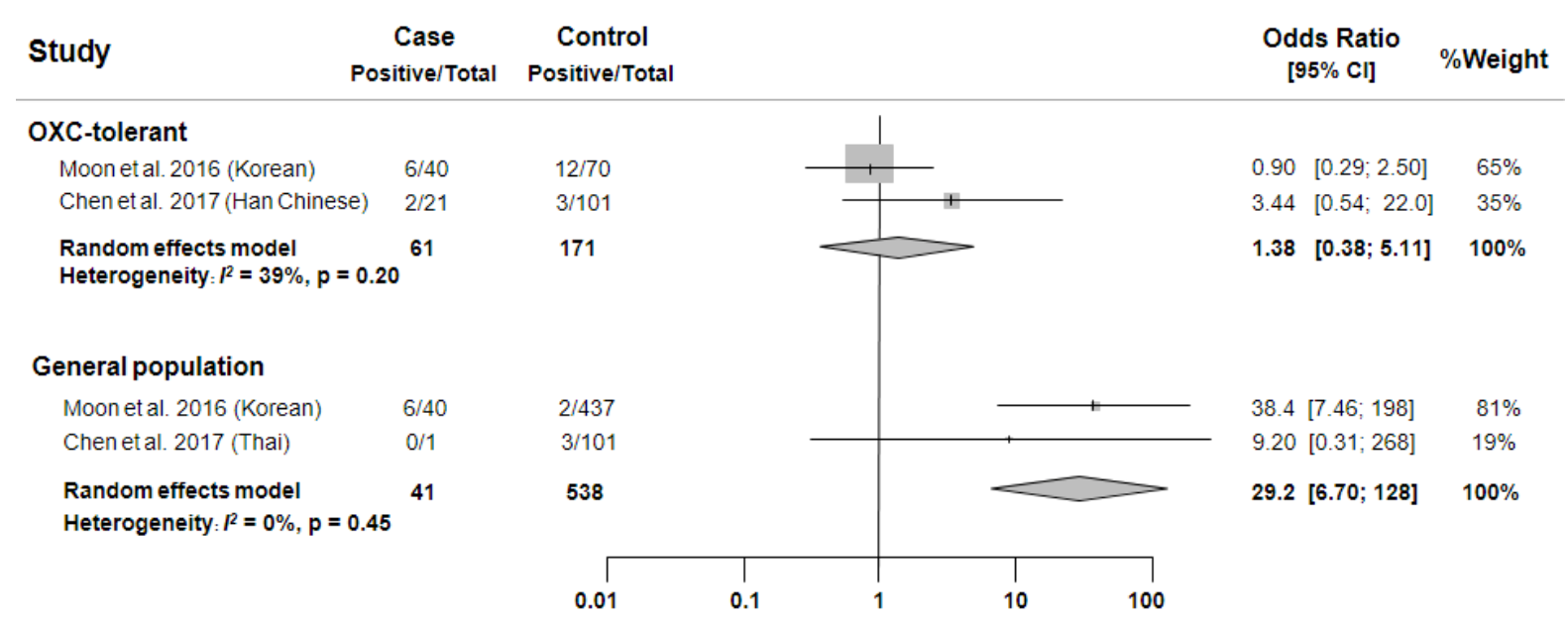

Figure 2 Forest plot of the associations between $H L A-A * 3101$ and $\mathrm{OXC}$-induced maculopapular rash 
(A) HLA-B*1502 \& Stevens-Johnson syndrome

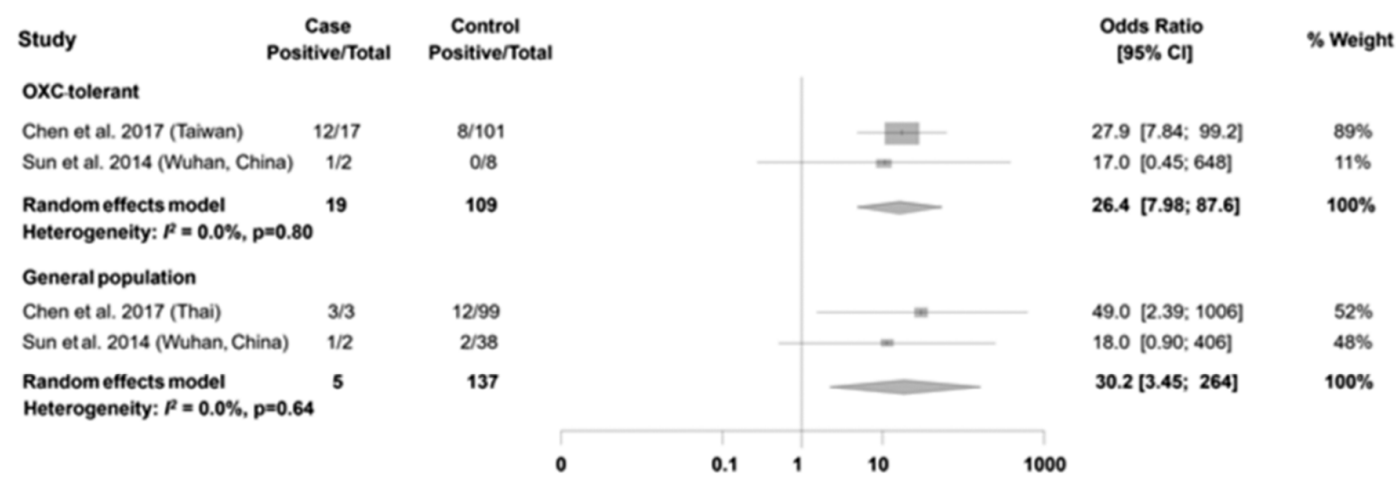

(B) HLA-B*1502 \& maculopapular rash

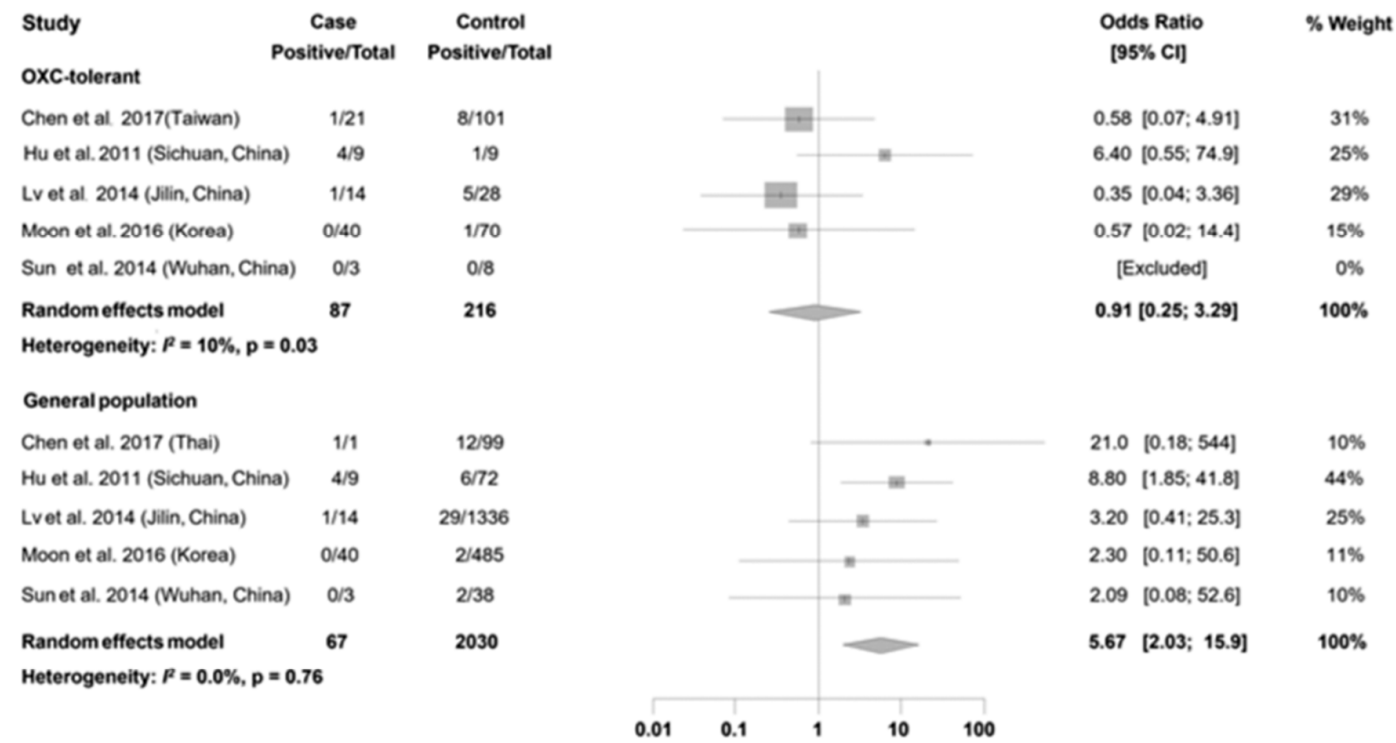

(C) HLA-B*1502 \& Stevens-Johnson syndrome and maculopapular rash

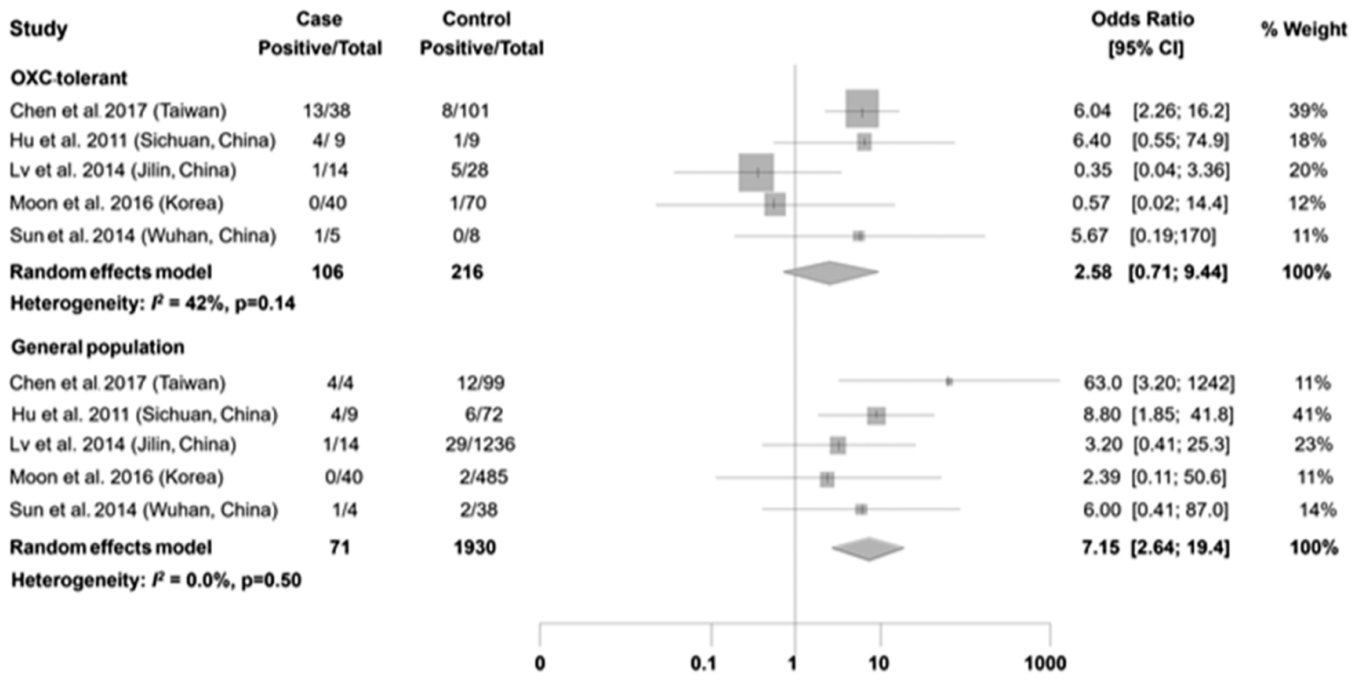

Figure 3 Forest plots of the associations between $H L A-B * 1502$ and $\mathrm{OXC}$-induced Stevens-Johnson syndrome (A), the associations between $H L A-B^{*} 1502$ and $\mathrm{OXC}$-induced maculopapular rash (B), and, the associations between $H L A$ $B * 1502$ and $\mathrm{OXC}$-induced Stevens-Johnson syndrome and maculopapular rash (C). 


\section{MHC class II and OXC-cADRs}

The associations between MHC class II and OXCcADRs are summarized in Table 3. Associations between $H L A-D Q B I^{*} 0501, \quad H L A-D Q B I^{*} 0503$, $H L A-D R B I^{*} 0403$, HLA-DRBI*0406, and HLA$D R B I^{*} 1405$ and with OXC-induced maculopapular rash in a Korean population were determined by Moon et al (21). HLA-DRBI*0403 was associated with $\mathrm{OXC}$-induced maculopapular rash by comparing cases with either the general population or the OXC-tolerant group as controls; $\mathrm{OR}=3.11 \quad(95 \% \mathrm{CI}=1.27-7.59) \quad$ and $\quad 14.64$ $(95 \% \mathrm{CI}=1.73-124)$, respectively (Table 3$)$.

\section{DISCUSSION}

To our knowledge, this is the first systematic review and meta-analysis study to identify the associations between HLA genotypes and OXCcADRs. In our study, 49 different HLA genotypes were identified as risks of OXC-cADRs but metaanalysis could be applied to only 4 of these (i.e., $H L A-A * 3101, H L A-B * 1501, H L A-B * 1502$, and $H L A-B^{*} 1511$ ). Of these HLA-A*3101 and HLA$B * 1502$ were associated with OXC-cADRs (Figure 2-3). All of the other HLA genotypes and OXCcADRs are summarized in Table 3.

Notably, we found associations between HLA$B^{*} 1502$ and OXC-induced SJS in both general population control and $\mathrm{OXC}$-tolerant groups. The ORs were close to those of the general population and OXC-tolerant control [OR $=30.2$ $(95 \% \mathrm{CI}=3.45-264)$ and $\mathrm{OR}=26.4(95 \% \mathrm{CI}=7.98$ 87.6), respectively] (Figure 3A). Nonetheless, due to limited number of studies, more studies investigating associations between $H L A-B * 1502$ and OXC-induced SJS/TEN are needed. In addition, $H L A-B * 1502$ was associated with OXCinduced maculopapular rash in general population controls $\quad(\mathrm{OR}=5.67,95 \% \mathrm{CI}=2.03-15.9) \quad$ (Figure $3 \mathrm{~B})$. To further investigate the associations between $H L A-B * 1502$ and OXC-induced maculopapular rash and SJS, we combined OXCinduced maculopapular rash groups with OXCinduced SJS groups. Then, $H L A-B * 1502$ was associated with the OXC-induced maculopapular $\mathrm{rash} / \mathrm{SJS}$ group, comparing the general population $[\mathrm{OR}=7.15 \quad(95 \% \mathrm{CI}=2.64-19.4)] \quad$ (Figure 3C). Nonetheless, the association between HLA$A^{*} 3101$ and $\mathrm{OXC}$-induced maculopapular rash was observed in general population controls $[\mathrm{OR}=29.2(95 \% \mathrm{CI}=6.70-128)]$ (Figure 2).

Other OXC-induced pathologies such as TEN are not well studied and, to our knowledge, are confined to studies where SJS and TEN data were pooled $(7,11,25)$. Thus, based on current findings and the previous studies, subjects harboring the allele might develop TEN when given OXC.

All of the included studies were from HanChinese, Thai and Korean populations (12-14, 2123). Whether these associations with OXC-cADRs are more widespread need large-scale studies in more ethnically diverse populations.

We found two studies $(21,23)$ that found associations between $H L A-A * 3101$ and OXCinduced cADRs while for CBZ-induced cADRs (i.e., maculopapular rash) other ethicities including Caucasian and Japanese are susceptible (26-30). Furthermore, associations between $H L A-A * 3101$ and CBZ-induced SJS/TEN were also reported in some studies $(26,30)$ which suggests that $H L A$ $A * 3101$ could also induce OXC-cADRs. Thus in further studies that we suggest using wider ethnic groups, a wider range of MHC genes should be included.

Recently, 3D molecular coupling models of HLA protein molecules and carbamazepine, oxcarbazepine and abacavir were developed (31, 32). These models shed an understanding of how HLA molecules binds specifically to their ligands and potentially causes those adverse drug reactions (i.e. Steven-Johnson syndrome, toxic epidermal necrolysis, DRESS) (31). Despite the structural similarities of $\mathrm{OXC}$ and $\mathrm{CBZ}$ and their reported cross-reactivity, OXC does not share the HLArelated risk factors with CBZ-induced SJS/TEN which are 30-40 folds more than for OXC in Han Chinese (24). In addition, some patients carrying $H L A-B * 1502$ with a history of CBZ-induced SJS could tolerate OXC (23). To understand the biological basis of this, the mechanism of the cross reactivity needs further studies.

\section{CONCLUSION}

Strong associations between the $H L A-B * 1502$ and OXC-cADRs (SJS and maculopapular rash) were found in both controls from cases using either control from either the general population or and OXC-tolerant groups. In general population controls, OXC-induced maculopapular rash was associated with $H L A-A * 3101$. These strong links were detected in Korean, Han-Chinese and Thai ethnicities. Therefore, a genetic screening in these ethnicities should precede an OXC treatment. For other populations, genetic screening of $H L A$ $B * 1502$ prior to OXC therapy may be warranted. However, screening for a wider range of both MHC genotype and ethnicities should be undertaken. 


\section{REFERENCES}

1. Kalis M, Huff N. Oxcarbazepine, an antiepileptic agent. Clin Ther. 2001 May;23(5):680-700.

2. McAuley J, Biederman T, Smith J, Moore J. Newer therapies in the drug treatment of epilepsy. Ann Pharmacother. 2002 Jan;36(1):119-29.

3. Yang C, Dao R, Lee T, Lu C, Yang C, Hung S, et al. Severe cutaneous adverse reactions to antiepileptic drugs in Asians. Neurology. $2011 \mathrm{Dec}$ 6;77(23):2025-33.

4. Alvestad S, Lydersen S, Brodtkorb E. Crossreactivity pattern of rash from current aromatic antiepileptic drugs. Epilepsy Res. 2008 Aug;80(23):194-200.

5. Hirsch L, Arif H, Nahm E, Buchsbaum R, Resor SJ, Bazil C. Cross-sensitivity of skin rashes with antiepileptic drug use. Neurology. 2008 Nov 4;71(19):1527-34.

6. Wang X, Lang S, Shi X, Tian H, Wang R, Yang F. Cross-reactivity of skin rashes with current antiepileptic drugs in Chinese population. Seizure. 2010 Nov;19(9):562-6.

7. Tangamornsuksan W, Chaiyakunapruk N, Somkrua R, Lohitnavy M, Tassaneeyakul W. Relationship Between the HLA-B*1502 Allele and Carbamazepine-Induced Stevens-Johnson Syndrome and Toxic Epidermal Necrolysis: A Systematic Review and Meta-analysis. JAMA Dermatol 2013 Sep 1;149(9):1025-32.

8. Li X, Yu K, Mei S, Huo J, Wang J, Zhu Y, et al. HLA-B*1502 increases the risk of phenytoin or lamotrigine induced Stevens-Johnson Syndrome/toxic epidermal necrolysis: evidence from a meta-analysis of nine case-control studies. Drug Res (Stuttg). 2015 Feb;65(2):107-11.

9. Chung W, Hung S, Chen Y. Human leukocyte antigens and drug hypersensitivity. Current Opinion in Allergy \& Clinical Immunology. 2007;7(4):317-23.

10. Bharadwaj M, Illing P, Kostenko L. Personalized medicine for HLA-associated drughypersensitivity reactions. Personalized Medicine. 2010;7(5):495-516.

11. Hung S, Chung WH, Liu ZS, Chen CH, Hsih MS, Hui $\mathrm{RC}$, et al. Common risk allele in aromatic antiepileptic-drug induced Stevens-Johnson syndrome and toxic epidermal necrolysis in Han Chinese. Pharmacogenomics. 2010 Mar;11(3):34956.

12. Hu F, Wu X, An D, Yan B, Stefan H, Zhou D. Pilot association study of oxcarbazepine-induced mild cutaneous adverse reactions with HLA-B*1502 allele in Chinese Han population. Seizure. 2011 Mar;20(2):160-2.

13. He N, Min FL, Shi YW, Guo J, Liu XR, Li BM, et al. Cutaneous reactions induced by oxcarbazepine in Southern Han Chinese: Incidence, features, risk factors and relation to HLA-B alleles. Seizure. 2012 Oct;21(8):614-8.
14. Sun D, Yu CH, Liu ZS, He XL, Hu JS, Wu GF, et al. Association of HLA-B*1502 and *1511 allele with antiepileptic drug-induced Stevens-Johnson syndrome in central China. J Huazhong Univ Sci Technolog Med Sci. 2014 Feb;34(1):146-50.

15. Smits K, Schouten J, Smits L, Stelma F, Nelemans $\mathrm{P}$, Prins M. A review on the design and reporting of studies on drug-gene interaction. J Clin Epidemiol. 2005;58(7):651-4.

16. Thakkinstian A, McElduff P, D'Este C, Duffy D, Attia J. A method formeta-analysis of molecular association studies. Stat Med. 2005;24(9):1291306.

17. Wells G, Shea B, O'Connell D, Peterson J, Welch $\mathrm{V}$, Losos M, et al. The Newcastle-Ottawa Scale (NOS) for assessing the quality of nonrandomised studies in meta-analyses. 2011; Available from: http://www.ohri.ca/programs/clinical_epidemiolog y/oxford.asp.

18. DerSimonian R, Laird N. Meta-analysis in clinical trials. Control Clin Trials. 1986;7(3):177-88.

19. Higgins J, Thompson S. Quantifying heterogeneity in a meta-analysis. Stat Med. 2002;21(11):1539-58.

20. Higgins J, Thompson S, Deeks J, Altman D. Measuring inconsistency in meta-analyses. BMJ. 2003 Sep 6;327(7414):557-60.

21. Moon J, Kim TJ, Lim JA, Sunwoo JS, Byun JI, Lee ST, et al. HLA-B*40:02 and DRB1*04:03 are risk factors for oxcarbazepine-induced maculopapular eruption. Epilepsia. 2016 Nov;57(11):1879-86.

22. Lv Y, Min FL, Liao WP, He N, Zeng T, Ma DH, et al. The association between oxcarbazepine-induced maculopapular eruption and HLA-B alleles in a northern Han Chinese population. BMC Neurol. 2013 Jul 8;13:75.

23. Chen C, Hsiao YH, Wu T, Hsih MS, Tassaneeyakul W, Jorns TP, et al. Risk and association of HLA with oxcarbazepine-induced cutaneous adverse reactions in Asians. Neurology. 2017 Jan 3;88(1):78-86.

24. Chen $\mathrm{YC}$, Chu CY, Hsiao $\mathrm{CH}$. Oxcarbazepineinduced Stevens-Johnson syndrome in a patient with HLA-B*1502 genotype. J Eur Acad Dermatol Venereol. 2009 Jun;23(6):702-3.

25. Nguyen D, Chu HC, Nguyen DV, Phan MH, Craig $\mathrm{T}$, Baumgart $\mathrm{K}$, et al. HLA-B*1502 and carbamazepine-induced severe cutaneous adverse drug reactions in Vietnamese. Asia Pac Allergy. 2015 Apr;5(2):68-77.

26. Genin E, Chen DP, Hung SI, Sekula P, Schumacher M, Chang PY, et al. HLA-A*31:01 and different types of carbamazepine-induced severe cutaneous adverse reactions: an international study and metaanalysis. Pharmacogenomics J. 2014 Jun;14(3):281-8.

27. Ozeki T, Mushiroda T, Yowang A, Takahashi A, Kubo M, Shirakata Y, et al. Genome-wide association study identifies HLA-A*3101 allele as a genetic risk factor for carbamazepine-induced 
cutaneous adverse drug reactions in Japanese population. Hum Mol Genet. 2011 Mar 1;20(5):1034-41.

28. Hung S, Chung WH, Jee SH, Chen WC, Chang YT, Lee WR, et al. Genetic susceptibility to carbamazepine-induced cutaneous adverse drug reactions. Pharmacogenet Genomics. 2006 Apr;16(4):297-306.

29. Amstutz U, Ross CJ, Castro-Pastrana LI, Rieder MJ, Shear NH, Hayden MR, et al. HLA-A 31:01 and HLA-B 15:02 as genetic markers for carbamazepine hypersensitivity in children. Clin Pharmacol Ther. 2013 Jul;94(1):142-9.

30. McCormack M, Alfirevic A, Bourgeois S, Farrell JJ, Kasperavičiūtė D, Carrington M, et al. HLA-
A*3101 and carbamazepine-induced hypersensitivity reactions in Europeans. N Engl J Med. 2011 Mar 24;364(12):1134-43.

31. Teh LK, Selvaraj M, Bannur Z, Ismail MI, Rafia H, Law WC, et al. Coupling Genotyping and Computational Modeling in Prediction of Antiepileptic Drugs that cause Stevens Johnson Syndrome and Toxic Epidermal Necrolysis for Carrier of HLA-B*15:02. J Pharm Pharm Sci. 2016;19(1):147-60.

32. Illing P, Vivian JP, Dudek NL, Kostenko L, Chen $\mathrm{Z}$, Bharadwaj $\mathrm{M}$, et al. Immune self-reactivity triggered by drug-modified HLA-peptide repertoire. Nature. 2012 Jun 28;486(7404):554-8. 
J Pharm Pharm Sci (www.cspsCanada.org) 21, 1 - 18, 2018

\begin{tabular}{|c|c|c|c|c|c|c|c|c|c|c|}
\hline \multirow[b]{2}{*}{ Author (Year) } & \multirow[b]{2}{*}{ Country } & \multirow[b]{2}{*}{ Ethnicity } & \multirow[b]{2}{*}{$\begin{array}{l}\text { Study } \\
\text { design }\end{array}$} & \multirow[b]{2}{*}{ cADRs } & \multirow[b]{2}{*}{$\begin{array}{c}\text { Case } \\
(\mathrm{N})\end{array}$} & \multirow[b]{2}{*}{ Control (N) } & \multicolumn{3}{|c|}{ MHC class I } & \multirow[b]{2}{*}{ MHC class II } \\
\hline & & & & & & & $\begin{array}{c}\text { HLA-A } \\
\text { genotypes }\end{array}$ & $\begin{array}{c}\text { HLA-B } \\
\text { genotypes }\end{array}$ & HLA-C genotypes & \\
\hline $\begin{array}{l}\text { Hu et al, } 2011 \\
(12)\end{array}$ & $\begin{array}{l}\text { Sichuan, } \\
\text { China }\end{array}$ & $\begin{array}{c}\text { Han } \\
\text { Chinese }\end{array}$ & Case control & MP rash & 9 & $\begin{array}{c}\text { OXC-tolerant: } 9 \\
\text { General population: } 72\end{array}$ & ND & $H L A-B * 1502$ & ND & ND \\
\hline $\begin{array}{l}\text { He et al, } 2012 \\
\text { (13) }\end{array}$ & $\begin{array}{c}\text { Guangzhou, } \\
\text { China }\end{array}$ & $\begin{array}{c}\text { Han } \\
\text { Chinese }\end{array}$ & $\begin{array}{c}\text { Prospective } \\
\text { cohort }\end{array}$ & MP rash & 14 & $\begin{array}{c}\text { OXC-tolerant: } 35 \\
\\
\\
\text { General population: } \\
264 \text { (southern Han } \\
\text { Chinese population), } \\
569 \text { (Hong Kong } \\
\text { Chinese population), } \\
106 \text { (Guangzhou Han } \\
\text { Chinese population) }\end{array}$ & ND & $\begin{array}{l}H L A-B * 1302 \\
H L A-B * 1501 \\
H L A-B * 1502 \\
H L A-B * 1519 \\
H L A-B * 1527 \\
H L A-B * 2704 \\
H L A-B * 2709 \\
H L A-B * 3905 \\
H L A-B * 4001 \\
H L A-B * 4601 \\
H L A-B * 4804 \\
H L A-B * 4901 \\
H L A-B * 5101 \\
H L A-B * 5401 \\
H L A-B * 5604\end{array}$ & ND & ND \\
\hline $\begin{array}{l}\text { Lv et al, } 2014 \\
\text { (22) }\end{array}$ & Jilin, China & $\begin{array}{c}\text { Han } \\
\text { Chinese }\end{array}$ & Case control & MP rash & 14 & $\begin{array}{c}\text { General population:618 } \\
\text { (Beijing Shijiazhuang } \\
\text { Tianjin Han } \\
\text { population), } 105 \text { (North } \\
\text { Han Chinese } \\
\text { population) }\end{array}$ & ND & $\begin{array}{l}H L A-B^{*} 0705 \\
H L A-B * 1301 \\
H L A-B^{*} 1302 \\
H L A-B^{*} 1301 \\
H L A-B * 1501 \\
H L A-B^{*} 1502 \\
H L A-B^{*} 1511 \\
H L A-B^{*} 1513 \\
H L A-B^{*} 1527 \\
H L A-B * 1542 \\
H L A-B * 1558 \\
H L A-B * 2705 \\
H L A-B * 3508 \\
H L A-B * 3531 \\
H L A-B * 3710 \\
H L A-B * 3801 \\
H L A-B * 3802 \\
H L A-B * 3901\end{array}$ & ND & ND \\
\hline
\end{tabular}


J Pharm Pharm Sci (www.cspsCanada.org) 21, 1 - 18, 2018

\begin{tabular}{|c|c|c|c|c|c|c|c|c|c|c|}
\hline $\begin{array}{c}\text { Table } 1 \\
\text { Continued... }\end{array}$ & & & & & & & & $\begin{array}{l}H L A-B * 4001 \\
H L A-B * 4006 \\
H L A-B * 4402 \\
H L A-B * 4403 \\
H L A-B * 4601 \\
H L A-B * 4701 \\
H L A-B * 4801 \\
H L A-B * 4804 \\
H L A-B * 5101 \\
H L A-B * 5102 \\
H L A-B * 5201 \\
H L A-B * 5301 \\
H L A-B * 5501 \\
H L A-B * 5502 \\
H L A-B * 5601 \\
H L A-B * 5604 \\
H L A-B * 5801\end{array}$ & & \\
\hline \multirow{3}{*}{$\begin{array}{l}\text { Sun et al, } 2014 \\
(14)\end{array}$} & \multirow{3}{*}{$\begin{array}{l}\text { Wuhan, } \\
\text { China }\end{array}$} & \multirow{3}{*}{$\begin{array}{l}\text { Han } \\
\text { Chinese }\end{array}$} & \multirow{3}{*}{ Case control } & MP rash & 1 & OXC-tolerant: 8 & \multirow{3}{*}{ ND } & \multirow{3}{*}{$H L A-B * 1502$} & \multirow{3}{*}{ ND } & \multirow{3}{*}{ ND } \\
\hline & & & & \multirow{2}{*}{ SJS } & \multirow{2}{*}{2} & $\begin{array}{c}\text { General population: } 38 \\
\text { OXC-tolerant: } 8\end{array}$ & & & & \\
\hline & & & & & & General population: 38 & & & & \\
\hline $\begin{array}{l}\text { Moon et al, } \\
2016(21)\end{array}$ & Korea & Korean & Case control & MP rash & 40 & OXC-tolerant: 70 & $\begin{array}{l}H L A-A * 3101 \\
H L A-A * 3201\end{array}$ & $\begin{array}{l}H L A-B^{*} 1501 \\
H L A-B * 1502 \\
H L A-B^{* 1511} \\
H L A-B^{*} 4002\end{array}$ & ND & $\begin{array}{c}H L A- \\
D Q B I^{*} 0501 \\
H L A- \\
D Q B I^{*} 0503 \\
H L A- \\
D R B I^{*} 0403 \\
H L A- \\
D R B I^{*} 0406 \\
H L A- \\
D R B I^{*} 1405\end{array}$ \\
\hline \multirow{5}{*}{$\begin{array}{l}\text { Chen et al, } 2017 \\
\text { (23) }\end{array}$} & \multirow{3}{*}{ Taiwan } & \multirow{3}{*}{$\begin{array}{l}\text { Han } \\
\text { Chinese }\end{array}$} & \multirow{5}{*}{ Case control } & MP rash & 21 & \multirow{3}{*}{$\begin{array}{l}\text { General population: } \\
101\end{array}$} & \multirow{5}{*}{$H L A-A * 3101$} & \multirow{5}{*}{$H L A-B^{*} 1502$} & \multirow{5}{*}{ ND } & \multirow{5}{*}{ ND } \\
\hline & & & & SJS & 17 & & & & & \\
\hline & & & & $\frac{\text { DRESS }}{\text { BFDE }}$ & $\begin{array}{c}6 \\
101\end{array}$ & & & & & \\
\hline & \multirow{2}{*}{ Thailand } & \multirow{2}{*}{ Thai } & & MP rash & 1 & \multirow{2}{*}{ OXC-tolerant: 99} & & & & \\
\hline & & & & SJS & 3 & & & & & \\
\hline
\end{tabular}




\section{Table 1. Continued...}

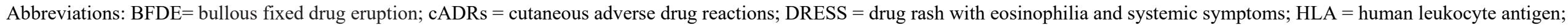
MP rash = maculopapular rash; ND = Not determined; OXC = oxcarbazepine; SJS = Stevens-Johnson syndrome.

\begin{tabular}{|c|c|c|c|c|c|c|c|c|c|}
\hline \multirow[b]{2}{*}{$\begin{array}{l}\text { Author } \\
\text { (Year) }\end{array}$} & \multirow[b]{2}{*}{ Country } & \multirow[b]{2}{*}{ Ethnicity } & \multirow[b]{2}{*}{$\begin{array}{l}\text { Type of } \\
\text { cADRs }\end{array}$} & \multirow[b]{2}{*}{ Definition of cADRs } & \multicolumn{2}{|c|}{ Diagnostic criteria } & \multirow[b]{2}{*}{$\begin{array}{l}\text { cADRs } \\
\text { evaluation }\end{array}$} & \multirow{2}{*}{$\begin{array}{l}\text { Assessing } \\
\text { attribution of } \\
\text { cADRs to } \\
\text { OXC }\end{array}$} & \multirow[b]{2}{*}{ NOS } \\
\hline & & & & & Case & Control & & & \\
\hline \multirow{2}{*}{$\begin{array}{l}\text { Hu et al, } \\
2011 \\
(12)\end{array}$} & \multirow[b]{2}{*}{$\begin{array}{l}\text { Sichuan, } \\
\text { China }\end{array}$} & \multirow[b]{2}{*}{$\begin{array}{l}\text { Han } \\
\text { Chinese }\end{array}$} & \multirow[b]{2}{*}{ MP rash } & \multirow{2}{*}{$\begin{array}{l}\text { MP rash was } \\
\text { characterized by } \\
\text { cutaneous itchy and } \\
\text { erythematous macules } \\
\text { and papules. }\end{array}$} & \multirow{2}{*}{$\begin{array}{l}\text { Subjects who had MP rash after } \\
\text { administration of antiepileptic } \\
\text { drugs, and spontaneously } \\
\text { resolved within } 1-2 \text { weeks after } \\
\text { withdrawing the causative drugs }\end{array}$} & $\begin{array}{l}\text { General population: Healthy } \\
\text { control }\end{array}$ & \multirow[b]{2}{*}{ NA } & \multirow[b]{2}{*}{ Epilepsy center } & \multirow[b]{2}{*}{6} \\
\hline & & & & & & $\begin{array}{l}\text { OXC-tolerant: Subjects who had } \\
\text { administered OXC more than } 3 \\
\text { months without any cADRs }\end{array}$ & & & \\
\hline \multirow[t]{2}{*}{$\begin{array}{l}\text { He et al, } \\
2012 \\
(13)\end{array}$} & \multirow[t]{2}{*}{$\begin{array}{l}\text { Guangzhou, } \\
\text { China }\end{array}$} & \multirow[t]{2}{*}{$\begin{array}{c}\text { Han } \\
\text { Chinese }\end{array}$} & \multirow[t]{2}{*}{ MP rash } & \multirow{2}{*}{$\begin{array}{l}\text { MP rash was } \\
\text { characterized by } \\
\text { erythematous exanthema } \\
\text { without blistering or } \\
\text { postulation. }\end{array}$} & \multirow{2}{*}{$\begin{array}{l}\text { Subjects who had initial } \\
\text { symptoms of cADRs within the } \\
\text { first } 8 \text { weeks of OXC } \\
\text { administration }\end{array}$} & $\begin{array}{l}\text { General population: Using the } \\
\text { HLA-B allele frequency reported } \\
\text { in the Allele Frequency Net } \\
\text { Database and Trachtenberg et al., } \\
2007\end{array}$ & \multirow[t]{2}{*}{ Dermatologist } & \multirow[t]{2}{*}{$\begin{array}{l}\text { Epileptologist } \\
\text { and } \\
\text { dermatologist }\end{array}$} & \multirow[t]{2}{*}{9} \\
\hline & & & & & & $\begin{array}{l}\text { OXC-tolerant: Subjects who had } \\
\text { administered OXC more than } 3 \\
\text { months without any cADRs }\end{array}$ & & & \\
\hline \multirow{2}{*}{$\begin{array}{l}\text { Lv et al, } \\
2014 \\
(22)\end{array}$} & \multirow[t]{2}{*}{ Jilin, China } & \multirow{2}{*}{$\begin{array}{l}\text { Han } \\
\text { Chinese }\end{array}$} & \multirow[t]{2}{*}{ MP rash } & \multirow{2}{*}{$\begin{array}{l}\text { MP rash was defined as } \\
\text { erythematous exanthema } \\
\text { without blistering or } \\
\text { postulation. }\end{array}$} & \multirow[t]{2}{*}{ NA } & $\begin{array}{l}\text { General population: Using the } \\
\text { HLA-B allele frequency reported } \\
\text { in the Allele Frequency Net } \\
\text { Database. }\end{array}$ & \multirow[t]{2}{*}{ NA } & \multirow{2}{*}{$\begin{array}{l}\text { Epileptologist } \\
\text { and } \\
\text { dermatologist }\end{array}$} & \multirow[t]{2}{*}{6} \\
\hline & & & & & & $\begin{array}{l}\text { OXC-tolerant: Subjects who had } \\
\text { administered OXC more than } 3 \\
\text { months without any cADRs }\end{array}$ & & & \\
\hline \multirow{2}{*}{$\begin{array}{l}\text { Sun et } \\
\text { al, } 2014 \\
(14)\end{array}$} & \multirow[b]{2}{*}{$\begin{array}{l}\text { Wuhan, } \\
\text { China }\end{array}$} & \multirow[b]{2}{*}{$\begin{array}{l}\text { Han } \\
\text { Chinese }\end{array}$} & MP rash & NA & Subjects who had cADRs within & $\begin{array}{l}\text { General population: Healthy Han } \\
\text { Chinese children }\end{array}$ & & & \\
\hline & & & SJS & $\begin{array}{l}\text { SJS was defined as skin } \\
\text { detachment of } 10 \% \text { of } \\
\text { total body-surface area. }\end{array}$ & $\begin{array}{l}\text { the first } 8 \text { weeks of exposure } \\
\text { with improvement after drug } \\
\text { withdrawal }\end{array}$ & $\begin{array}{l}\text { OXC-tolerant: Subjects who had } \\
\text { been on OXC for more than } 2 \\
\text { months and no cADRs }\end{array}$ & NA & Dermatologists & 6 \\
\hline $\begin{array}{l}\text { Moon et } \\
\text { al, } 2016 \\
(21)\end{array}$ & Korea & Korean & MP rash & NA & $\begin{array}{l}\text { Patients who experienced OXC- } \\
\text { induced MP rash }\end{array}$ & $\begin{array}{l}\text { General population: Using the } \\
\text { HLA-B allele frequency reported } \\
\text { Lee et al, } 2005\end{array}$ & NA & NA & 5 \\
\hline
\end{tabular}


J Pharm Pharm Sci (www.cspsCanada.org) 21, 1 - 18, 2018

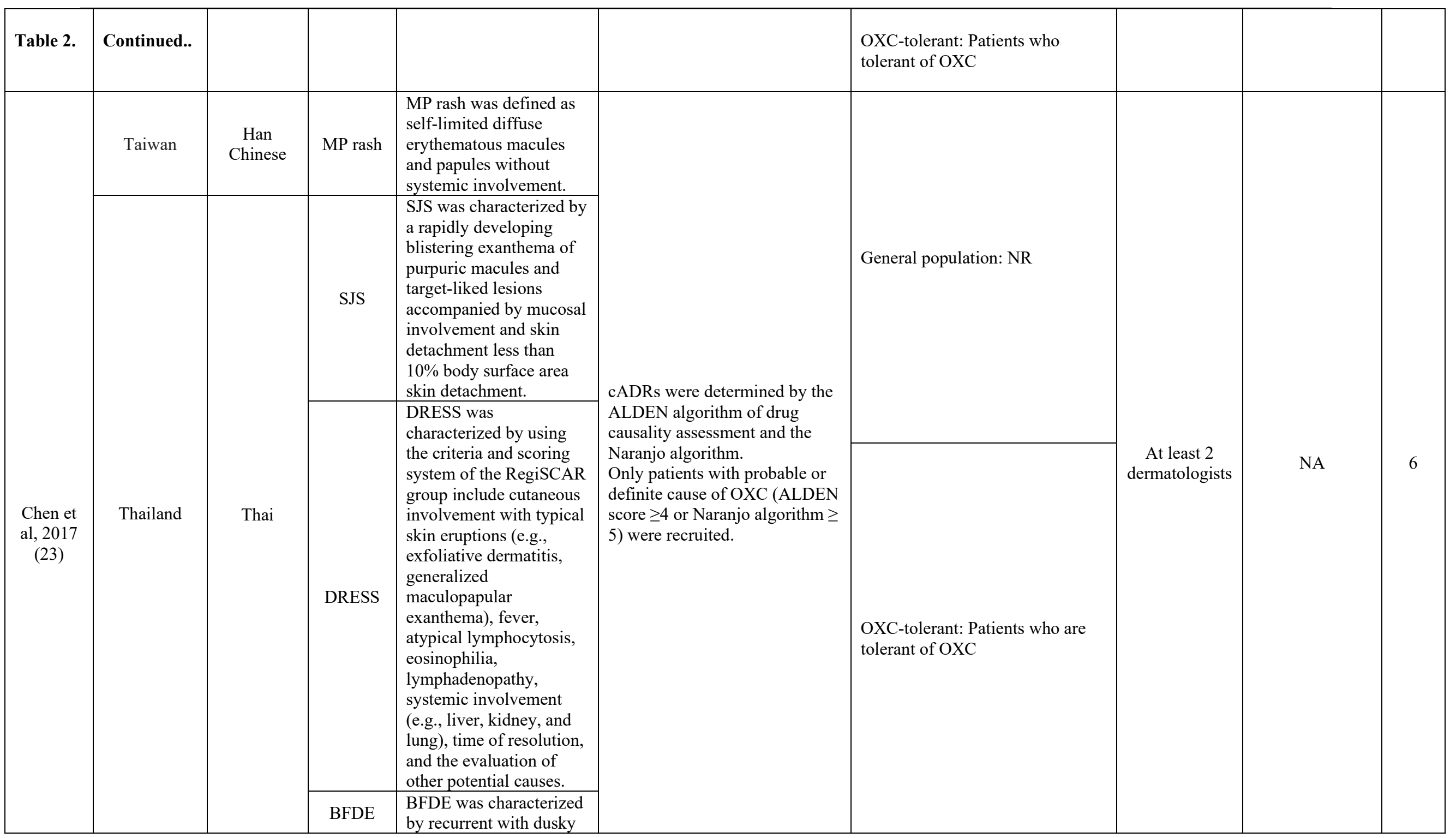


J Pharm Pharm Sci (www.cspsCanada.org) 21, 1 - 18, 2018

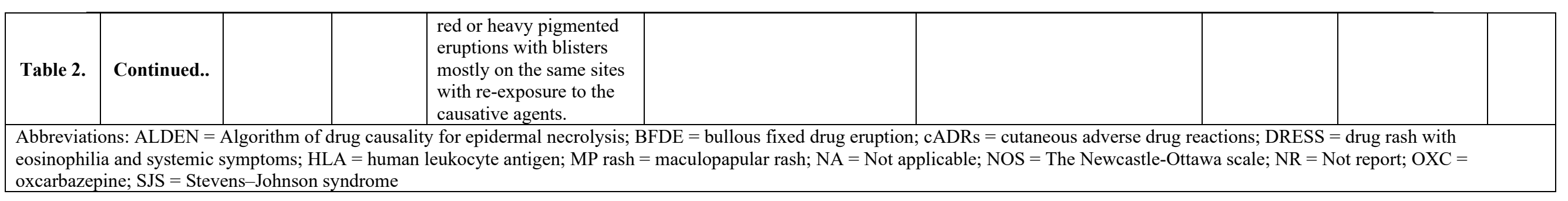

Table 3. Summary odds ratios of the included studies categorized by HLA genotypes and OXC-cADRs

\begin{tabular}{|c|c|c|c|c|c|c|c|c|c|c|}
\hline \multirow[b]{2}{*}{ HLA genotypes } & \multirow[b]{2}{*}{ cADRs } & \multirow[b]{2}{*}{ Author } & \multirow[b]{2}{*}{ Year } & \multirow[b]{2}{*}{ Race (Country) } & \multirow[b]{2}{*}{ Study design } & \multicolumn{2}{|c|}{ Case } & \multicolumn{2}{|c|}{ Control } & \multirow[b]{2}{*}{ OR $(95 \% C l)$} \\
\hline & & & & & & $\begin{array}{c}\text { HLA } \\
\text { positive }\end{array}$ & $\begin{array}{c}\text { HLA } \\
\text { negative }\end{array}$ & $\begin{array}{c}\text { HLA } \\
\text { positive }\end{array}$ & $\begin{array}{c}\text { HLA } \\
\text { negative }\end{array}$ & \\
\hline \multicolumn{11}{|l|}{ MHC class I } \\
\hline \multicolumn{11}{|c|}{ HLA-A genotypes } \\
\hline \multirow{16}{*}{$H L A-A * 3101$} & \multirow{8}{*}{ MP rash } & \multicolumn{9}{|c|}{ General population control } \\
\hline & & Moon et al (21) & 2016 & Korean (Korea) & Case control & 6 & 34 & 2 & 483 & $38.4(7.46-198)$ \\
\hline & & Chen et al (23) & 2017 & Thai (Thailand) & Case control & 0 & 1 & 3 & 96 & $9.20(0.31-268)$ \\
\hline & & \multicolumn{8}{|c|}{ Subtotal $\left(I^{2}=0.0 \%, \mathrm{P}=0.45\right)$} & $29.2(6.70-128)^{\mathrm{a}}$ \\
\hline & & \multicolumn{9}{|l|}{ OXC-tolerant } \\
\hline & & Moon et al (21) & 2016 & Korean (Korea) & Case control & 6 & 34 & 12 & 58 & $0.90(0.29-2.50)$ \\
\hline & & Chen et al (23) & 2017 & Han Chinese (Taiwan) & Case control & 2 & 19 & 3 & 98 & $3.44(0.54-22.0)$ \\
\hline & & \multicolumn{8}{|c|}{ Subtotal $\left(I^{2}=39 \%, \mathrm{P}=0.20\right)$} & $1.38(0.38-5.11)$ \\
\hline & \multirow{4}{*}{ SJS } & \multicolumn{9}{|c|}{ General population control } \\
\hline & & Chen et al (23) & 2017 & Thai (Thailand) & Case control & 0 & 3 & 3 & 96 & $3.94(0.17-91.9)$ \\
\hline & & \multicolumn{9}{|l|}{ OXC-tolerant } \\
\hline & & Chen et al (23) & 2017 & Han Chinese (Taiwan) & Case control & 1 & 16 & 3 & 98 & $2.04(0.20-20.9)$ \\
\hline & & \multicolumn{9}{|l|}{ OXC-tolerant } \\
\hline & DRESS & Chen et al (23) & 2017 & Han Chinese (Taiwan) & Case control & 0 & 6 & 3 & 98 & $2.16(0.10-46.5)$ \\
\hline & קחГ & \multicolumn{9}{|l|}{ OXC-tolerant } \\
\hline & BFDE & Chen et al (23) & 2017 & Han Chinese (Taiwan) & Case control & 0 & 2 & 3 & 98 & $5.63(0.23-141)$ \\
\hline
\end{tabular}




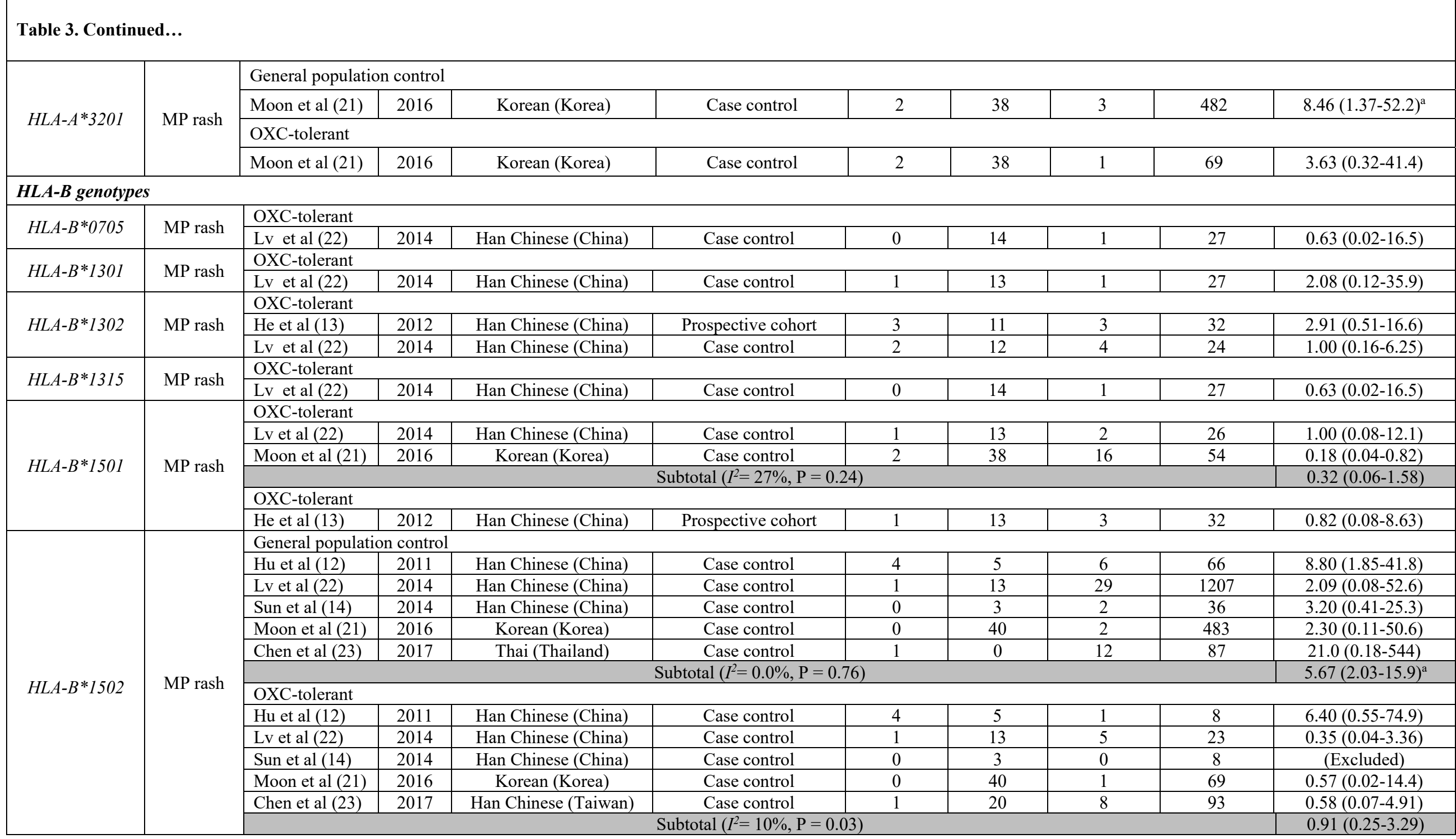




\begin{tabular}{|c|c|c|c|c|c|c|c|c|c|c|}
\hline \multirow{28}{*}{$\begin{array}{c}\text { Table } 3 . \\
\text { Continued... }\end{array}$} & & \multicolumn{9}{|l|}{ OXC-tolerant } \\
\hline & & He et al (13) & 2012 & Han Chinese (China) & Prospective cohort & 1 & 13 & 2 & 33 & $1.27(0.11-15.2)$ \\
\hline & \multirow{8}{*}{ SJS } & \multicolumn{9}{|c|}{ General population control } \\
\hline & & Sun et al (14) & 2014 & Han Chinese (China) & Case control & 1 & 1 & 2 & 36 & $18.0(0.90-406)$ \\
\hline & & Chen et al (23) & 2017 & Thai (Thailand) & Case control & 3 & 0 & 12 & 87 & $49.0(2.39-1006)$ \\
\hline & & \multicolumn{8}{|c|}{ Subtotal $\left(I^{2}=0.0 \%, \mathrm{P}=0.80\right)$} & $30.2(3.45-264)^{\mathrm{a}}$ \\
\hline & & \multicolumn{9}{|l|}{ OXC-tolerant } \\
\hline & & Sun et al (14) & 2014 & Han Chinese (China) & Case control & 1 & 1 & 0 & 8 & $17.0(0.45-648)$ \\
\hline & & Chen et al (23) & 2017 & Han Chinese (Taiwan) & Case control & 12 & 5 & 8 & 93 & $27.9(7.84-99.2)$ \\
\hline & & \multicolumn{8}{|c|}{ Subtotal $\left(I^{2}=0.0 \%, \mathrm{P}=0.64\right)$} & $26.4(7.98-87.6)^{a}$ \\
\hline & \multirow{14}{*}{$\begin{array}{c}\mathrm{MP} \\
\text { rash+SJS }\end{array}$} & \multicolumn{9}{|c|}{ General population control } \\
\hline & & Hu et al (12) & 2011 & Han Chinese (China) & Case control & 4 & 5 & 6 & 66 & $8.80(1.85-41.8)$ \\
\hline & & Lv et al (22) & 2014 & Han Chinese (China) & Case control & 1 & 13 & 29 & 1207 & $3.20(0.41-25.3)$ \\
\hline & & Sun et al (14) & 2014 & Han Chinese (China) & Case control & 1 & 3 & 2 & 36 & $6.00(0.41-87.0)$ \\
\hline & & Moon et al (21) & 2016 & Korean (Korea) & Case control & 0 & 40 & 2 & 483 & $2.39(0.11-50.6)$ \\
\hline & & Chen et al (23) & 2017 & Thai (Thailand) & Case control & 4 & 0 & 12 & 87 & $63.0(3.20-1242)$ \\
\hline & & \multicolumn{8}{|c|}{ Subtotal $\left(I^{2}=0.0 \%, \mathrm{P}=0.50\right)$} & $7.15(2.64-19.4)^{a}$ \\
\hline & & \multicolumn{9}{|l|}{ OXC-tolerant } \\
\hline & & Hu et al (12) & 2011 & Han Chinese (China) & Case control & 4 & 5 & 1 & 8 & $6.40(0.55-74.9)$ \\
\hline & & Lv et al (22) & 2014 & Han Chinese (China) & Case control & 1 & 13 & 5 & 23 & $0.35(0.04-3.36)$ \\
\hline & & Sun et al (14) & 2014 & Han Chinese (China) & Case control & 1 & 4 & 0 & 8 & $5.67(0.19-170)$ \\
\hline & & Moon et al (21) & 2016 & Korean (Korea) & Case control & 0 & 40 & 1 & 69 & $0.57(0.02-14.4)$ \\
\hline & & Chen et al (23) & 2017 & Han Chinese (Taiwan) & Case control & 13 & 25 & 8 & 93 & $6.04(2.26-16.2)$ \\
\hline & & \multicolumn{8}{|c|}{ Subtotal $\left(I^{2}=42 \%, \mathrm{P}=0.14\right)$} & $2.58(0.71-9.44)$ \\
\hline & \multirow{2}{*}{ DRESS } & \multicolumn{9}{|l|}{ OXC-tolerant } \\
\hline & & Chen et al (23) & 2017 & Han Chinese (Taiwan) & Case control & 0 & 6 & 8 & 93 & $2.20(0.10-49.7)$ \\
\hline & \multirow{2}{*}{ BFDE } & \multicolumn{9}{|l|}{ OXC-tolerant } \\
\hline & & Chen et al (23) & 2017 & Han Chinese (Taiwan) & Case control & 0 & 2 & 8 & 93 & $0.85(0.04-16.3)$ \\
\hline \multirow{6}{*}{$H L A-B * 1511$} & \multirow{6}{*}{ MP rash } & \multicolumn{9}{|c|}{ General population control } \\
\hline & & Moon et al (21) & 2016 & Korean (Korea) & Case control & 1 & 39 & 19 & 466 & $0.63(0.11-6.97)$ \\
\hline & & \multicolumn{9}{|l|}{ OXC-tolerant } \\
\hline & & Lv et al (22) & 2014 & Han Chinese (China) & Case control & 0 & 14 & 2 & 26 & $0.37(0.02-8.14)$ \\
\hline & & Moon et al (21) & 2016 & Korean (Korea) & Case control & 1 & 39 & 1 & 69 & $1.77(0.11-29.1)$ \\
\hline & & \multicolumn{8}{|c|}{ Subtotal $\left(I^{2}=0.0 \%, \mathrm{P}=0.46\right)$} & $0.87(0.11-6.97)$ \\
\hline \multirow{2}{*}{$H L A-B * 1513$} & \multirow{2}{*}{ MP rash } & \multicolumn{9}{|l|}{ OXC-tolerant } \\
\hline & & Lv et al (22) & 2014 & Han Chinese (China) & Case control & 0 & 14 & 1 & 27 & $0.63(0.02-16.5)$ \\
\hline$H I A-B * 1510$ & & OXC-tolerant & & & & & & & & \\
\hline$H L A-B+1519$ & MP rash & He et al (13) & 2012 & Han Chinese (China) & Prospective cohort & 1 & 13 & 0 & 35 & $7.89(0.30-206)$ \\
\hline$H L A-B * 1527$ & MP rash & OXC-tolerant & & & & & & & & \\
\hline
\end{tabular}


J Pharm Pharm Sci (www.cspsCanada.org) 21, 1 - 18, 2018

\begin{tabular}{|c|c|c|c|c|c|c|c|c|c|c|}
\hline \multirow{2}{*}{$\begin{array}{c}\text { Table } 3 . \\
\text { Continued... }\end{array}$} & & He et al (13) & 2012 & Han Chinese (China) & Prospective cohort & 2 & 12 & 0 & 35 & $14.0(0.64-316)$ \\
\hline & & Lv et al (22) & 2014 & Han Chinese (China) & Case control & 1 & 13 & 0 & 28 & $6.33(0.24-166)$ \\
\hline \multirow{2}{*}{$H L A-B * 1542$} & \multirow{2}{*}{ MP rash } & \multicolumn{9}{|l|}{ OXC-tolerant } \\
\hline & & Lv et al (22) & 2014 & Han Chinese (China) & Case control & 1 & 13 & 0 & 28 & $6.33(0.24-166)$ \\
\hline \multirow{2}{*}{$H L A-B * 1558$} & \multirow{2}{*}{ MP rash } & \multicolumn{9}{|l|}{ OXC-tolerant } \\
\hline & & Lv et al (22) & 2014 & Han Chinese (China) & Case control & 1 & 13 & 0 & 28 & $6.33(0.24-166)$ \\
\hline \multirow{2}{*}{$H L A-B * 2704$} & \multirow{2}{*}{ MP rash } & \multicolumn{9}{|l|}{ OXC-tolerant } \\
\hline & & He et al (13) & 2012 & Han Chinese (China) & Prospective cohort & 2 & 12 & 0 & 35 & $14.2(0.64-316)$ \\
\hline \multirow{2}{*}{$H L A-B * 2705$} & \multirow{2}{*}{ MP rash } & \multicolumn{9}{|l|}{ OXC-tolerant } \\
\hline & & Lv et al (22) & 2014 & Han Chinese (China) & Case control & 0 & 14 & 1 & 27 & $0.63(0.02-16.5)$ \\
\hline \multirow{2}{*}{$H L A-B * 2709$} & \multirow{2}{*}{ MP rash } & OXC-tolerant & & & & & & & & \\
\hline & & He et al (13) & 2012 & Han Chinese (China) & Prospective cohort & 1 & 13 & 0 & 35 & $7.89(0.30-206)$ \\
\hline \multirow{2}{*}{$H L A-B * 3508$} & \multirow{2}{*}{ MP rash } & OXC-tolerant & & & & & & & & \\
\hline & & Lv et al (22) & 2014 & Han Chinese (China) & Case control & 0 & 14 & 1 & 27 & $0.63(0.02-16.5)$ \\
\hline \multirow{2}{*}{$H L A-B * 3531$} & \multirow{2}{*}{ MP rash } & OXC-tolerant & & & & & & & & \\
\hline & & Lv et al (22) & 2014 & Han Chinese (China) & Case control & 0 & 14 & 2 & 26 & $0.37(0.02-8.14)$ \\
\hline \multirow{2}{*}{$H L A-B * 3710$} & \multirow{2}{*}{ MP rash } & OXC-tolerant & & & & & & & & \\
\hline & & Lv et al (22) & 2014 & Han Chinese (China) & Case control & 0 & 14 & 1 & 27 & $0.63(0.02-16.5)$ \\
\hline \multirow{2}{*}{$H L A-B * 3801$} & \multirow{2}{*}{ MP rash } & OXC-tolerant & & & & & & & & \\
\hline & & Lv et al (22) & 2014 & Han Chinese (China) & Case control & 0 & 14 & 1 & 27 & $0.63(0.02-16.5)$ \\
\hline \multirow{2}{*}{$H L A-B * 3802$} & \multirow{2}{*}{ MP rash } & OXC-tolerant & & & & & & & & \\
\hline & & Lv et al (22) & 2014 & Han Chinese (China) & Case control & 3 & 11 & 2 & 25 & $3.41(0.50-23.7)$ \\
\hline & & OXC-tolerant & & & & & & & & \\
\hline$H L A-B * 3901$ & MP rash & Lv et al (22) & 2014 & Han Chinese (China) & Case control & 0 & 14 & 1 & 27 & $0.63(0.02-16.5)$ \\
\hline & & OXC-tolerant & & & & & & & & \\
\hline$H L A-B \curvearrowright 390 J$ & MP rash & He et al (13) & 2012 & Han Chinese (China) & Prospective cohort & 1 & 13 & 0 & 35 & $7.89(0.30-206)$ \\
\hline & & OXC-tolerant & & & & & & & & \\
\hline$H L A-B * 4001$ & MP rash & He et al (13) & 2012 & Han Chinese (China) & Prospective cohort & 3 & 11 & 10 & 25 & $0.68(0.16-2.97)$ \\
\hline & & Lv et al (22) & 2014 & Han Chinese (China) & Case control & 2 & 12 & 4 & 24 & $1.00(0.16-6.25)$ \\
\hline & & General populat & 1 contro & & & & & & & \\
\hline$H I A-R * 4002$ & MP rash & Moon et al (21) & 2016 & Korean (Korea) & Case control & 10 & 30 & 37 & 448 & $4.04(1.83-8.90)^{\mathrm{a}}$ \\
\hline ПLA-D $400 Z$ & MIP rash & OXC-tolerant & & & & & & & & \\
\hline & & Moon et al (21) & 2016 & Korean (Korea) & Case control & 10 & 30 & 5 & 65 & $4.33(1.36-13.8)^{\mathrm{a}}$ \\
\hline$H I A R * 1006$ & & OXC-tolerant & & & & & & & & \\
\hline$H L A-B \times 4006$ & MP rash & Lv et al (22) & 2014 & Han Chinese (China) & Case control & 0 & 14 & 1 & 27 & $0.63(0.02-16.5)$ \\
\hline & & OXC-tolerant & & & & & & & & \\
\hline$H L A-B * 4402$ & MP rash & Lv et al (22) & 2014 & Han Chinese (China) & Case control & 1 & 13 & 0 & 28 & $6.33(0.24-166)$ \\
\hline
\end{tabular}


J Pharm Pharm Sci (www.cspsCanada.org) 21, 1 - 18, 2018

\begin{tabular}{|c|c|c|c|c|c|c|c|c|c|c|}
\hline $\begin{array}{c}\text { Table } 3 . \\
\text { Continued... }\end{array}$ & & & & & & & & & & \\
\hline \multirow{2}{*}{$H L A-B^{*} 4403$} & \multirow{2}{*}{ MP rash } & \multicolumn{9}{|l|}{ OXC-tolerant } \\
\hline & & Lv et al (22) & 2014 & Han Chinese (China) & Case control & 2 & 12 & 4 & 24 & $1.00(0.16-6.25)$ \\
\hline \multirow{3}{*}{$H L A-B * 4601$} & \multirow{3}{*}{ MP rash } & OXC-tolerant & & & & & & & & \\
\hline & & He et al (13) & 2012 & Han Chinese (China) & Prospective cohort & 3 & 11 & 11 & 24 & $0.60(0.14-2.6)$ \\
\hline & & Lv et al (22) & 2014 & Han Chinese (China) & Case control & 1 & 13 & 3 & 25 & $0.64(0.06-6.79)$ \\
\hline \multirow{2}{*}{$H L A-B * 4701$} & \multirow{2}{*}{ MP rash } & OXC-tolerant & & & & & & & & \\
\hline & & Lv et al (22) & 2014 & Han Chinese (China) & Case control & 0 & 14 & 1 & 27 & $0.63(0.02-16.5)$ \\
\hline \multirow{2}{*}{$H L A-B * 4801$} & \multirow{2}{*}{ MP rash } & OXC-tolerant & & & & & & & & \\
\hline & & Lv et al (22) & 2014 & Han Chinese (China) & Case control & 0 & 14 & 4 & 24 & $0.19(0.01-3.74)$ \\
\hline \multirow{3}{*}{$H L A-B^{*} 4804$} & \multirow{3}{*}{ MP rash } & OXC-tolerant & & & & & & & & \\
\hline & & He et al (13) & 2012 & Han Chinese (China) & Prospective cohort & 1 & 13 & 0 & 35 & $7.89(0.30-206)$ \\
\hline & & Lv et al (22) & 2014 & Han Chinese (China) & Case control & 0 & 14 & 1 & 24 & $0.56(0.02-14.8)$ \\
\hline \multirow{2}{*}{$H L A-B * 4901$} & \multirow{2}{*}{ MP rash } & OXC-tolerant & & & & & & & & \\
\hline & & He et al (13) & 2012 & Han Chinese (China) & Prospective cohort & 1 & 13 & 0 & 35 & $7.89(0.30-206)$ \\
\hline \multirow{3}{*}{$H L A-B * 5101$} & \multirow{3}{*}{ MP rash } & OXC-tolerant & & & & & & & & \\
\hline & & He et al (13) & 2012 & Han Chinese (China) & Prospective cohort & 1 & 13 & 3 & 32 & $0.82(0.08-8.63)$ \\
\hline & & Lv et al (22) & 2014 & Han Chinese (China) & Case control & 1 & 13 & 1 & 27 & $2.08(0.12-35.9)$ \\
\hline \multirow{2}{*}{$H L A-B * 5102$} & \multirow{2}{*}{ MP rash } & OXC-tolerant & & & & & & & & \\
\hline & & Lv et al (22) & 2014 & Han Chinese (China) & Case control & 0 & 14 & 1 & 27 & $0.63(0.02-16.5)$ \\
\hline \multirow{2}{*}{$H L A-B * 5201$} & \multirow[b]{2}{*}{ MP rash } & OXC-tolerant & & & & & & & & \\
\hline & & Lv et al (22) & 2014 & Han Chinese (China) & Case control & 1 & 13 & 0 & 28 & $6.33(0.24-166)$ \\
\hline \multirow{2}{*}{$H L A-B * 5301$} & \multirow{2}{*}{ MP rash } & OXC-tolerant & & & & & & & & \\
\hline & & Lv et al (22) & 2014 & Han Chinese (China) & Case control & 1 & 13 & 0 & 28 & $6.33(0.24-166)$ \\
\hline \multirow{2}{*}{$H L A-B * 5401$} & \multirow{2}{*}{ MP rash } & OXC-tolerant & & & & & & & & \\
\hline & & He et al (13) & 2012 & Han Chinese (China) & Prospective cohort & 1 & 13 & 0 & 35 & $7.89(0.30-206)$ \\
\hline \multirow{2}{*}{$H L A-B * 5501$} & \multirow{2}{*}{ MP rash } & OXC-tolerant & & & & & & & & \\
\hline & & Lv et al (22) & 2014 & Han Chinese (China) & Case control & 0 & 14 & 1 & 27 & $0.63(0.02-16.5)$ \\
\hline \multirow{2}{*}{$H L A-B^{*} 5502$} & & OXC-tolerant & & & & & & & & \\
\hline & MP rash & Lv et al (22) & 2014 & Han Chinese (China) & Case control & 1 & 13 & 1 & 27 & $2.08(0.12-35.9)$ \\
\hline$H I A R * 5601$ & & OXC-tolerant & & & & & & & & \\
\hline$H L A-B+5001$ & MP rash & Lv et al (22) & 2014 & Han Chinese (China) & Case control & 1 & 13 & 0 & 28 & $6.33(0.24-166)$ \\
\hline & & OXC-tolerant & & & & & & & & \\
\hline$H L A-B * 5604$ & MP rash & He et al (13) & 2012 & Han Chinese (China) & Prospective cohort & 1 & 13 & 0 & 35 & $7.89(0.30-206)$ \\
\hline & & Lv et al (22) & 2014 & Han Chinese (China) & Case control & 0 & 14 & 1 & 27 & $0.63(0.02-16.5)$ \\
\hline$H L A-B * 5801$ & MP rash & OXC-tolerant & & & & & & & & \\
\hline
\end{tabular}


J Pharm Pharm Sci (www.cspsCanada.org) 21, 1 - 18, 2018

\begin{tabular}{|c|c|c|c|c|c|c|c|c|c|c|}
\hline $\begin{array}{c}\text { Table } 3 . \\
\text { Continued... }\end{array}$ & & Lv et al (22) & 2014 & Han Chinese (China) & Case control & 0 & 14 & 3 & 25 & $0.25(0.01-5.21)$ \\
\hline \multicolumn{11}{|l|}{ MHC class II } \\
\hline \multirow{4}{*}{$\begin{array}{c}H L A- \\
D Q B I^{*} 0501\end{array}$} & \multirow{4}{*}{ MP rash } & \multicolumn{9}{|c|}{ General population control } \\
\hline & & Moon et al (21) & 2016 & Korean (Korea) & Case control & 1 & 39 & 3 & 482 & $4.12(0.42-40.54)$ \\
\hline & & \multicolumn{9}{|l|}{ OXC-tolerant } \\
\hline & & Moon et al (21) & 2016 & Korean (Korea) & Case control & 1 & 39 & 7 & 63 & $0.23(0.03-1.95)$ \\
\hline \multirow{4}{*}{$\begin{array}{c}H L A- \\
D Q B I^{*} 0503\end{array}$} & \multirow{4}{*}{ MP rash } & \multicolumn{9}{|c|}{ General population control } \\
\hline & & Moon et al (21) & 2016 & Korean (Korea) & Case control & 3 & 37 & 46 & 439 & $0.77(0.23-2.61)$ \\
\hline & & \multicolumn{9}{|l|}{ OXC-tolerant } \\
\hline & & Moon et al (21) & 2016 & Korean (Korea) & Case control & 3 & 37 & 14 & 56 & $0.31(0.09-1.21)$ \\
\hline \multirow{4}{*}{$\begin{array}{c}H L A- \\
D R B I^{*} 0403\end{array}$} & \multirow{4}{*}{ MP rash } & \multicolumn{9}{|c|}{ General population control } \\
\hline & & Moon et al (21) & 2016 & Korean (Korea) & Case control & 7 & 33 & 31 & 454 & $3.11(1.27-7.59)^{\mathrm{a}}$ \\
\hline & & \multicolumn{9}{|l|}{ OXC-tolerant } \\
\hline & & Moon et al (21) & 2016 & Korean (Korea) & Case control & 7 & 33 & 1 & 69 & $14.64(1.73-124)^{\mathrm{a}}$ \\
\hline \multirow{4}{*}{$\begin{array}{c}H L A- \\
D R B I^{*} 0406\end{array}$} & \multirow{4}{*}{ MP rash } & \multicolumn{9}{|c|}{ General population control } \\
\hline & & Moon et al (21) & 2016 & Korean (Korea) & Case control & 2 & 38 & 39 & 446 & $0.60(0.14-2.59)$ \\
\hline & & \multicolumn{9}{|l|}{ OXC-tolerant } \\
\hline & & Moon et al (21) & 2016 & Korean (Korea) & Case control & 2 & 38 & 11 & 59 & $0.28(0.06-1.34)$ \\
\hline \multirow{4}{*}{$\begin{array}{c}H L A- \\
D R B I^{*} 1405\end{array}$} & \multirow{4}{*}{ MP rash } & \multicolumn{9}{|c|}{ General population control } \\
\hline & & Moon et al (21) & 2016 & Korean (Korea) & Case control & 3 & 37 & 22 & 463 & $1.71(0.49-5.97)$ \\
\hline & & \multicolumn{9}{|l|}{ OXC-tolerant } \\
\hline & & Moon et al (21) & 2016 & Korean (Korea) & Case control & 3 & 37 & 11 & 59 & $0.43(0.11-1.66)$ \\
\hline
\end{tabular}

